\title{
Efforts To Coaching Competence of Teacher Guidance And Counseling (Descriptive Study in High School Se-Rejang Lebong)
}

\section{Tamama Rofiqah *}

\author{
Division of Counseling and Guidance, University, of Riau Kepulauan, Batam
}

\begin{abstract}
Abstrak
Sentral pengembangan BK, secara spesifik difokuskan kepada kompetensi guru BK.Keterandalan guru BK dalam menampilkan kinerja dapat menumbuhkan kepercayaan publik maupun akuntabilitas, sehingga profesi ini semakin diakui dan dimanfaatkan keberadaannya.Kompetensi itu perlu dibakukan, dicapai sesuai harapan tiap guru BK di sekolah.Kepala sekolah selaku penanggung jawab seluruh penyelenggaraan pendidikan di sekolah memegang peranan strategis dalam mengembangkan layanan BK di sekolah.Salah satu peran kepala sekolah dalam peningkatan kompetensi guru BK dilakukan melalui berbagai upaya pembinaan dan pelatihan.
\end{abstract}

Keyword: competence

\section{Pendahuluan}

Tuntutan kualifikasi pendidikan dicapai melalui hubungan yang erat dengan manusia (dasar filosofis).Manusia utuh hanya dapat dicapai melalui pendidikan tuntas, yang mencerminkan manusia kaffah, dalam arti satunya niat, pikir, ucap, perilaku dan tujuan yang direalisasikan dalam hidup bermasyarakat.Dalam perspektif filosofis ini hendaknya pendidikan, khususnya Bimbingan dan Konseling (selanjutnya disingkat BK) dikembangkan.Lebih spesifik lagi yaitu kompetensi guru BK. Dengan kompetensi guru BK yang memadai dilengkapi dengan profesionalitas dalam melaksanakan pelayanan, diharapkan dapat menghasilkan individu/siswa yang utuh.

Sentral pengembangan BK, secara spesifik difokuskan kepada kompetensi guru BK dalam menampilkan kinerja tertinggi yang ditujukan kepada sasaran pelayanan.Kompetensi guru BK tersebut dikembangkan dengan mengacu pada pandangan hakikat manusia.Keterandalan guru BK dalam menampilkan kinerja dapat menumbuhkan kepercayaan publik maupun akuntabilitas, sehingga profesi ini semakin diakui dan dimanfaatkan keberadaannya.Kompetensi itu perlu dibakukan, dicapai sesuai harapan tiap guru BK di sekolah.

Peraturan Pemerintah Republik Indonesia No. 19 Tahun 2005 tentang Standar Nasional Pendidikan Bab IV pasal 28 ayat 3 , menyatakan bahwa kompetensi guru sebagai agen pembelajaran pada jenjang pendidikan dasar dan menengah serta pendidikan anak usia dini meliputi : kompetensi pedagogik, kompetensi kepribadian, kompetensi sosial dan kompetensi profesional. Pernyataan di atas, dipertegas dalam Undang-undang No.14 Tahun 2005 tentang Guru dan Dosen pasal 10 ayat 1 yang menyebutkan bahwa kompetensi guru meliputi kompetensi pedagogik, kompetensi kepribadian, kompetensi sosial dan kompetensi profesional.

Oleh karena itu, guru BK seperti juga guru pada umumnya dituntut untuk memiliki keempat kompetensi seperti tersebut di atas, baik kompetensi pedagogik, kompetensi kepribadian, kompetensi sosial maupun kompetensi profesional.Karena untuk mencapai pelayanan yang bermutu dalam mengembangkan siswa secara optimal, dibutuhkan guru BK yang berkompeten dalam memberikan pelayanan melalui kinerja yang berkualitas.

Berkenaan dengan kinerja guru BK, Kurniawan (2010) dalam penelitiannya tentang kompetensi profesional konselor sekolah menengah negeri Se-Kota Banda Aceh dan Implikasinya bagi Pemerintah Kota Banda Aceh, mengungkapkan bahwa secara umum kompetensi konselor pada SMP dan SMA Negeri se-Kota Banda Aceh berada pada kriteria tinggi. Hal ini dilihat dari faktor-faktor yang mendukung kompetensi tersebut seperti mendapat pelatihan yang memadai tentang BK, bangga menjalankan tugas sebagai guru BK dan dukungan dari pihak sekolah terhadap pelayanan $\mathrm{BK}$.

Keberhasilan penyelenggaraan pelayanan BK di sekolah tidak lepas dari peran berbagai pihak di sekolah.Maju mundurnya sebuah institusi pendidikan tergantung kepala sekolah dalam mengatur sejauhmana aturan dan kedisiplinan di dalam menjalankan tugas dan fungsi masing-masing individu di dalamnya.Begitu juga dengan keberhasilan penyelenggaraan BK di sekolah khususnya, tidak lepas dari peranan berbagai pihak di sekolah.Selain guru BK atau konselor sebagai pelaksana utama penyelenggaraan bimbingan di sekolah, diperlukan juga keterlibatan kepala sekolah, guru mata pelajaran, dan wali kelas. 
Kepala sekolah selaku penanggung jawab seluruh penyelenggaraan pendidikan di sekolah memegang peranan strategis dalam mengembangkan layanan BK di sekolah. Prayitno (1997) menyatakan tugas kepala sekolah adalah:

1. Mengkoordinir segenap kegiatan yang diprogramkan dan berlangsung di sekolah, sehingga pelayanan pengajaran, latihan, dan BK merupakan suatu kesatuan yang terpadu, harmonis, dan dinamis.

2. Menyediakan sarana dan pra sarana, tenaga dan berbagai kemudahan bagi terlaksananya pelayanan BK yang efektif dan efisien.

3. Melakukan pengawasan dan pembinaan terhadap perencanaan dan pelaksanaan program, penilaian dan upaya tindak lanjut pelayanan BK

4. Mempertanggungjawabkan pelaksanaan pelayanan BK di sekolah kepada kanwil/kandep yang menjadi atasannya.

Mengacu kepada tugas kepala sekolah di atas, hendaknya kepala sekolah mampu mengkoordinir segenap kegiatan BK, menyediakan sarana prasarana, melakukan pengawasan dan pembinaan serta mempertanggung jawabkannya kepada atasan. Penelitian ini bertujuan untuk mendeskripsikan upaya pembinaan yang dilakukan oleh kepala sekolah dalam meningkatkan kompetensi guru BK di sekolah.

\section{Landasan Teori}

\section{Pengertian Kompetensi Guru}

Prayitno (2005) mengatakan bahwa kompetensi merupakan pengetahuan, keterampilan, nilai, sikap dasar yang direfleksikan dalam kebiasaan berpikir dan bertindak yang bersifat dinamis, berkembang dan dapat diraih setiap waktu.Kebiasaan berpikir dan bertindak secara konsisten dan terus menerus memungkinkan seseorang menjadi berkompeten, dalam arti memiliki pengetahuan, keterampilan, nilai dan sikap dasar dalam melakukan sesuatu.

Sedangkan Undang-undang No.14 Tahun 2005, tentang Guru dan Dosen, menjelaskan bahwa "kompetensi adalah seperangkat pengetahuan, keterampilan dan perilaku yang harus dimiliki, dihayati dan dikuasai oleh guru atau dosen dalam melaksanakan tugas keprofesionalan." Dari uraian tersebut, tampak bahwa kompetensi mengacu pada kemampuan melaksanakan sesuatu yang diperoleh melalui pendidikan, kompetensi guru menunjuk pada performan dan perbuatan yang rasional untuk memenuhi spesifikasi tertentu dalam pelaksanaan tugastugasnya.Dikatakan rasional karena mempunyai arah dan tujuan, sedangkan performan merupakan perilaku nyata dalam arti tidak hanya dapat diamati tetapi mencakup sesuatu yang tidak kasat mata.

Berkaitan dengan guru, Oemar Hamalik (2002) memberikan pengertian kompetensi guru dengan kemampuan melaksanakan kewajiban-kewajiban secara bertanggung jawab dan layak. Selanjutnya, Broke and Stone (dalam Mulyasa, 2007) mengemukakan bahwa kompetensi guru sebagai..descriptive of qualitative nature of teacher behavior appears to be entirely meaningful... "kompetensi guru merupakan gambaran kualitatif tentang hakikat perilaku guru yang penuh arti." Sementara Charles (dalam Mulyasa, 2007) menyatakan bahwa :competency as rational performance which satisfactory meets the objective for a desired condition, "kompetensi merupakan perilaku yang rasional untuk mencapai tujuan yang dipersyaratkan sesuai dengan kondisi yang diharapkan."

Dari beberapa paparan ahli di atas, dapat disimpulkan bahwa kompetensi adalah kemampuan yang dimiliki oleh seorang guru dalam hal penguasaan tugas dan keterampilan, sikap serta apresiasi baik kualitatif maupun kuantitatif. Kompetensi guru ini meliputi kompetensi pedagogik, kompetensi kepribadian, kompetensi sosial dan kompetensi profesional yang diperoleh melalui pendidikan profesi

\section{Standar Kompetensi Guru BK \\ Kompetensi Pedagogik}

Dalam Standar Nasional Pendidikan, penjelasan pasal 28 ayat 3 butir (a) dikemukakan bahwa kompetensi pedagogik adalah kemampuan mengelola pembelajaran peserta didik yang meliputi pemahaman terhadap peserta didik, perancangan dan pelaksanaan pembelajaran, evaluasi hasil pembelajaran dan pengembangan peserta didik.

Berkaitan dengan guru BK di sekolah, kompetensi pedagogik guru BK mengacu kepada Peraturan Pemerintah No. 27 Tahun 2008 tentang SKAKK yang menjelaskan bahwa kompetensi pedagogik konselor meliputi : (1) menguasai teori dan praksis pendidikan, (2) mengaplikasikan perkembangan fisiologis dan psikologis serta perilaku konseli, dan (3) menguasai esensi pelayanan BK dalam jalur, jenis dan jenjang satuan pendidikan.

Berdasarkan teori yang telah dikemukakan di atas, maka disimpulkan kompetensi pedagogik guru BK meliputi pemahaman guru BK terhadap klien/siswa, perancangan dan pelaksanaan pelayanan BK, evaluasi hasil pelayanan BK dan pengembangan klien/siswa.

\section{Kompetensi Kepribadian}

Dalam Standar Nasional Pendidikan, penjelasan pasal 28 ayat 3 butir (b) dikemukakan bahwa yang dimaksud dengan kompetensi kepribadian adalah kemampuan kepribadian yang mantap, stabil, dewasa, arif dan berwibawa, menjadi teladan bagi peserta didik dan berakhlak mulia. Syaiful Bahri Djamarah (2001) menyatakan bahwa setiap guru mempunyai pribadi masing-masing sesuai dengan ciri-ciri pribadi yang mereka miliki.Ciri-ciri inilah yang membedakan antara guru yang satu dengan yang lainnya, termasuk guru BK di sekolah. Kepribadian sebenarnya 
adalah suatu masalah yang abstr dalam menghadapi setiap masalal

Tamama Rofiqah / Jurnal Kopasta 3 (2016) 32 - 39

berpakaian dan

Di samping itu, kualitas prıbadı guru BK tersebut juga ditunjang oleh berbagaı kompetensi yang harus dikuasai oleh guru BK, terutama kompetensi kepribadian. Berdasarkan teori yang telah dipaparkan di atas, maka disimpulkan kompetensi kepribadian guru BK meliputi kepribadian guru BK yang mantap, kepribadian guru BK yang stabil, kepribadian guru BK yang dewasa, kepribadian guru BK arif dan berwibawa, menjadi teladan bagi klien/siswadan berakhlak mulia.

\section{Kompetensi Sosial}

Damsar (2011) mengemukakan bahwa kompetensi sosial meliputi subkompetensi dengan indikator efektif berupa: (1) mampu berkomunikasi dan bergaul secara efektif dengan sesama pendidik, (2) mampu berkomunikasi dan bergaul secara efektif dengan sesama pendidik dan tenaga kependidikan, (3) mampu berkomunikasi dan bergaul secara efektif dengan orang tua/wali peserta didik dan masyarakat sekitar.

Selanjutnya, Prayitno (2010) mengemukakan bahwa kompetensi sosial meliputi kemampuan guru BK dalam mengimplementasikan kolaborasi intern di tempat kerja, guru BK berperan dalam organisasi dan kegiatan profesi BK dan kemampuan guru BK dalam mengimplementasikan kolaborasi antar profesi. Pendapat Prayitno ini merujuk kepada Permendiknas No. 27 Tahun 2008 tentang Standar Kualifikasi Akademik dan Kompetensi Konselor.

Dari pendapat di atas, dapat disimpulkan bahwa kompetensi sosial merupakan kemampuan seorang guru dalam menjalin relasi sosial dengan orang lain yang ditandai dengan interaksi efektif dan efisien. Kompetensi sosial guru BK ini meliputi: kemampuan guru BK untuk berkomunikasi dan berinteraksi secara efektif dan efisien dengan klien/siswa, sesama guru, orang tua/wali klien/siswa dan masyarakat sekitar.

\section{Kompetensi Profesional}

Syaiful Bahri Djamarah (1991) mengemukakan bahwa kompetensi profesional guru mencakup penguasaan terhadap bahan/materi pembelajaran, pengelolaan kelas, materi dan sumber belajar, landasan dan teori kependidikan terutama yang berkaitan dengan perkembangan siswa.

Pendapat di atas, diperjelas oleh Prayitno (2010) yang mengemukakan bahwa kompetensi profesional guru BK meliputi (1) penguasaan konsep dan praksis assesmen untuk memahami kondisi, kebutuhan, dan masalah sasaran layanan, (2) penguasaan kerangka teoritik dan praksis BK, (3) merancang program BK, (4) mengimplementasikan program BK yang komprehensif, (5) menilai proses dan hasil kegiatan BK, (6) memiliki kesadaran dan komitmen terhadap etika profesional dan (7) menguasai konsep dan praksis penelitian dalam BK.

Berdasarkan pendapat di atas, dapat disimpulkan bahwa kompetensi profesional guru BK meliputi penguasaan konsep dan praksis assesmen untuk memahami kondisi, kebutuhan, dan masalah sasaran layanan, penguasaan kerangka teoritik dan praksis BK, merangcang program BK, implementasi program BK, menilai proses dan hasil kegiatan, memiliki kesadaran dan komitmen terhadap etika profesional dan menguasai konsep dan praksis penelitian dalam BK.

\section{Upaya Pembinaan Kompetensi Guru \\ Pengertian Pembinaan}

Wiyono (dalam Sunoko, 2011) mengatakan bahwa pembinaan adalah kegiatan untuk memberi bantuan, terutama bimbingan, pengawasan dan dorongan.Dari pengertian di atas, disimpulkan bahwa pembinaan merupakan kegiatan yang dilakukan untuk memperoleh hasil yang lebih baik dengan adanya bantuan yakni berupa bimbingan, pengawasan dan dorongan.Dengan bantuan tersebut diharapkan hasil yang diperoleh dari pembinaan dapat berdaya guna dan berhasil guna.

Berkaitan dengan pembinaan guru di sekolah, Sahertian (2000) menyatakan bahwa pembinaan bertujuan untuk memberikan pelayanan dan bantuan pada guru agar berubah sesuai dengan perkembangan yang ada untuk meningkatkan kualitas guru di kelasnya. Sedangkan Pidarta (dalam Sunoko, 2011) mengemukakan pembinaan guru adalah proses pengembangan kompetensi guru secara maksimum sesuai dengan tingkat kemampuannya, sehingga tercapai tingkat efisiensi kerja yang lebih tinggi.

Depdiknas (2004) menegaskan bahwa tanggung jawab pembinaan guru adalah berada di tangan pembina. Adapun yang dimaksud pembina adalah kepala sekolah dan pengawas sekolah, dan pembina lainnya adalah pimpinan yayasan, kepala dinas pendidikan tingkat kecamatan, kepala dinas pendidikan tingkat kabupaten/kota madya dan kepala dinas pendidikan tingkat provinsi. Senada dengan ungkapan di atas, Alfonso (dalam Sunoko, 2011) juga menyatakan bahwa perilaku belajar siswa ditentukan oleh perilaku gurunya.Sedangkan perilaku mengajar guru ditentukan oleh perilaku pembinanya.Alfonso menggambarkan bahwa terdapat pengaruh antara perilaku pembina terhadap perilaku mengajar guru dan perilaku belajar siswa.

Dari berbagai paparan di atas, yang dimaksud dengan pembinaan pada penelitian ini adalah kegiatan yang dilakukan oleh kepala sekolah terhadap guru BK berupa dorongan, bimbingan dan pengawasan yang bertujuan meningkatkan kualitas guru BK di sekolah melalui peningkatan kompetensi guru BK yakni kompetensi pedagogik, kompetensi kepribadian, kompetensi sosial dan kompetensi profesional.

\section{Berbagai Bentuk Pembinaan}

Mulyasa (2003) menyebutkan bahwa pembinaan guru dapat dilakukan dengan caraon the job training dan in the job training. Sementara Castetter (dalam Syaefudin, 2009) menyampaikan lima model pengembangan untuk guru yaitu model (1) Individual Guided Staff Development (Pengembangan guru yang dipadu secara individual), (2) 
Observation/Assessment (Observasi atau penilaian), (3) Involvement in a development/Improvement Process (keterlibatan dalam suatu proses pengembangan/peningkatan), (4) Training (Pelatihan), dan (5) Inquiry (Pemeriksaan). Direktorat Jenderal Pendidikan Dasar dan Menengah Departemen Pendidikan Nasional (dalamSyaefudin, 2009) menyebutkan beberapa alternatif program pengembangan profesionalisme guru, sebagai berikut:

1) Program peningkatan kualifikasi pendidikan guru

2) Program penyetaraan dan sertifikasi

3) Program pelatihan terintegrasi berbasis kompetensi

4) Program supervisi pendidika

5) Program pemberdayaan MGMP

6) Simposium guru

7) Program pelatihan tradisional lainnya

8) Membaca dan menulis jurnal atau karya ilmiah

9) Berpartisipasi dalam pertemuan ilmiah

10) Melakukan penelitian (PTK)

11) Magang

12) Mengikuti berita aktual dari media pemberitaan

13) Berpartisipasi dan aktif dalam organisasi profesi

14) Menggalang kerjasama dengan teman sejawat

Selanjutnya, Menurut Mega Iswari (2010), menyatakan bahwa bentuk pelatihan dan pembinaan bagi guru paling tidak dilaksanakan dalam dua bentuk yaitu (1) refreshing inservice training, yakni model pelatihan yang bertujuan memberikan konsep-konsep aktual tentang perubahan paradigma pendidikan, dan (2) enrichment inservice training, yakni model pelatihan yang bertujuan memberikan suplemen pengetahuan dan keterampilan yang dirasakan mendesak dan fungsional bagi guru. Ada beberapa upaya lain yang dapat dilakukan dalam rangka pengembangan kompetensi guru BK, yaitu sebagai berikut:

1) Program Pendidikan Profesi Konselor

2) Seminar

3) Musyawarah Kerja

\section{Kepala Sekolah sebagai Pembina}

Upaya pembinaan yang dilakukan oleh kepala sekolah dapat diwujudkan melalui pelaksanaan fungsi dan peran sebagai pemimpin, manajer dan supervisor di sekolah.Sahertian (2000) mengemukakan bahwa kepala sekolah dalam membina guru terutama dilakukan melalui fungsi sebagai seorang supervisor. Dalam hal ini kepala sekolah dapat berperan sebagai: (1) koordinator, (2) konsultan, (3) pemimpin kelompok, dan (4) evaluator. Kepala sekolah sebagai seorang supervisor berarti berfungsi untuk membantu, memberi dan mengikutsertakan seluruh sumber daya sekolah.

Senada dengan pendapat di atas, Briggs (dalam Sahertian, 2000) mengemukakan bahwa pelaksanaan pembinaan guru melalui pelaksanaan fungsi utama kepala sekolah sebagai supervisor pendidikan bukan hanya perbaikan pembelajaran saja, tetapi untuk mengkoordinasi, menstimulasi dan mendorong ke arah pertumbuhan profesi guru. Dengan kata lain bahwa fungsi supervisor adalah memperbaiki situasi proses pembelajaran dalam arti yang luas.

Selanjutnya, Lovell dan Wiles (dalam Sunoko, 2011) menyatakan bahwa pembinaan guru yang dilakukan oleh kepala sekolah dapat dilakukan melalui perwujudan 8 (delapan) fungsi supervisor pendidikan, yaitu: (1) mengkoordinasi semua usaha sekolah, (2) memperlengkapi kepemimpinan sekolah, (3) memperluas pengalaman guru-guru, (4) menstimulasi usaha-usaha yang kreatif, (5) memberi fasilitas dan penilaian yang terus menerus, (6) menganalisis situasi pembelajaran, (7) memberi pengetahuan dan keterampilan kepada setiap anggota staf, dan (8) memberi wawasan yang lebih luas dan terintegrasi dalam merumuskan tujuan-tujuan pendidikan dan meningkatkan kemampuan guru dalam proses pembelajaran.

Dari beberapa pendapat di atas, dapat dipahami bahwa kepala sekolah merupakan pembina para guru di sekolah sesuai dengan fungsi dan perannya sebagai pemimpin sekolah yaitu fungsi manajer dan supervisor.Tetapi sebagai pemimpin di sekolah, pembinaan yang dilakukan oleh kepala sekolah tidak terbatas hanya pada fungsi manajer dan supervisor saja, melainkan seluruh fungsi kepala sekolah.Hal ini dijelaskan oleh Depdikbud (1998) bahwa kepala sekolah dapat melakukan pembinaan kepada guru melalui peran kepala sekolah sebagai educator, motivator, administrator, supervisor, leader, inovator dan manager.

Pembinaan yang dilakukan ini memiliki tujuan-tujuan tertentu.Sahertian (2000) mengemukakan tujuan pembinaan adalah memberikan layanan dan bantuan untuk meningkatkan kualitas mengajar guru di kelas yang pada gilirannya untuk meningkatkan kualitas belajar siswa, bukan saja memperbaiki kemampuan belajar siswa tapi juga untuk pengembangan potensi kualitas guru.

Selanjutnya, Djajadisastra (dalam Sunoko, 2011) mengemukakan tujuan pembinaan adalah: (1) memperbaiki tujuan khusus mengajar guru dan belajar siswa, (2) memperbaiki materi dan kegiatan pembelajaran, (3) memperbaiki metode, yaitu cara mengorganisasi kegiatan pembelajaran, (4) memperbaiki penilaian dalam proses pembelajaran dan hasilnya, (5) memperbaiki penilaian atas media, (6) memperbaiki pembimbingan siswa atas kesulitan belajarnya, dan (7) memperbaiki sikap guru atas tugasnya.

\section{Metodologi}


Jenis penelitian ini adalah penelitian deskriptif. Lehman (dalam A. Muri Yusuf, 2005) menyatakan bahwa penelitian deskriptif yaitu suatu penelitian yang mendeskripsikan secara sistematis, faktual dan akurat mengenai fakta-fakta dan sifat populasi tertentu atau mencoba menggambarkan fenomena secara detail. Instrumen yang digunakan untuk mendeskripsikan upaya pembinaan yang dilakukan oleh kepala sekolah adalah dengan wawancara.Data hasil wawancara dianalisis dengan cara naratif, maksudnya jawaban yang diperoleh dari pertanyaan yang diajukan akan dideskripsikan dan selanjutnya ditarik kesimpulan.

\section{Temuan Penelitian dan Pembahasan}

Pembinaan merupakan kegiatan yang dilakukan untuk memperoleh hasil yang lebih baik dengan adanya bantuan berupa bimbingan, pengawasan dan dorongan.Dengan bantuan tersebut diharapkan hasil yang diperoleh dari pembinaan dapat berdaya guna dan berhasil guna. Deskripsi data tentang upaya pembinaan yang dilakukan oleh kepala sekolah untuk meningkatkan kompetensi guru BK, diperoleh melalui wawancara kepada responden penelitian. Adapun hasil wawancara kepada responden penelitian dapat diuraikan pada temuan sebagai berikut:

a. Gambaran tentang Pelayanan BK pada SMANegeri di Kabupaten Rejang Lebong

Gambaran tentang pelayanan BK pada SMA Negeri di Kabupaten Rejang Lebong diperoleh berdasarkan hasil wawancara kepada beberapa orang guru BK berkenaan dengan pemahaman personel sekolah terhadap pelayanan BK dan unjuk kerja guru BK. Adapun hasil wawancara berkenaan dengan pemahaman personel sekolah dapat dilihat pada Tabel 1 berikut:

\section{Tabel 1. Hasil Wawancara Berkenaan dengan Pemahaman Personel Sekolah terhadap Pelayanan BK}

\begin{tabular}{|c|l|l|}
\hline $\begin{array}{c}\text { N } \\
\mathbf{0}\end{array}$ & \multicolumn{1}{|c|}{ Pemahaman personel sekolah } & \multicolumn{1}{c|}{ Responden } \\
\hline 1 & $\begin{array}{l}\text { Pemahaman personel sekolah sudah baik } \\
\text { terhadap pelayanan BK karena mereka } \\
\text { merasakan manfaat pelayanan BK di sekolah }\end{array}$ & $\begin{array}{l}\text { Guru BK SMA N 1 Curup Timur dan SMA N 1 } \\
\text { Curup Tengah }\end{array}$ \\
\hline 2 & $\begin{array}{l}\text { Sebagian personel sekolah masih } \\
\text { menganggap bahwa pelayanan BK ditujukan } \\
\text { untuk siswa bermasalah }\end{array}$ & $\begin{array}{l}\text { Guru BK SMA N1 Selupu Rejang dan SMA N1 } \\
\text { Curup Kota }\end{array}$ \\
\hline 3 & $\begin{array}{l}\text { Guru BK boleh mengajar mata pelajaran } \\
\text { tertentu }\end{array}$ & Guru BK SMA N 1 Curup Utara \\
\hline 4 & \begin{tabular}{l} 
Layanan yang dilakukan bersifat klasikal saja \\
\cline { 2 - 3 }
\end{tabular} & $\begin{array}{l}\text { Pelayanan BK diarahkan ke pengembangan } \\
\text { karir siswa }\end{array}$ \\
\hline
\end{tabular}

Berdasarkan hasil wawancara pada Tabel di atas, pada SMA Negeri 1 Curup Timur dan SMA Negeri 1 Curup Tengah, pemahaman personel sekolah terhadap pelayanan BK bisa dikatakan baik karena manfaat dari pelayanan BK sudah dapat dirasakan oleh personel sekolah. Sedangkan pada SMA Negeri 1 Selupu Rejang dan SMA Negeri 1 Curup Kota, sebagian personel sekolah masih menganggap bahwa pelayanan BK ditujukan untuk siswa bermasalah.Begitu pula pada SMA Negeri 1 Curup Utara, guru BK dianggap seperti halnya guru mata pelajaran serta pelayanan BK yang dilakukan baru bersifat klasikal saja seperti pemberian layanan informasi.Pada SMA Negeri 1 Curup Selatan menganggap bahwa pelayanan BK diarahkan kepada pengembangan karir siswa.

Selanjutnya, hasil wawancara berkenaan dengan unjuk kerja guru BK di sekolah dapat dilihat pada Tabel 2 berikut:

\section{Tabel 2. Hasil Wawancara Berkenaan dengan Unjuk Kerja Guru BK}

\begin{tabular}{|c|l|l|}
\hline $\begin{array}{c}\text { N } \\
\mathbf{o}\end{array}$ & \multicolumn{1}{|c|}{ Kegiatan yang telah dilaksanakan } & \multicolumn{1}{|c|}{ Yang menjalani } \\
\hline $\mathbf{1}$ & \multicolumn{1}{|c|}{$\mathbf{2}$} & \\
\hline 1 & Sudah baik dan dapat dilihat dalam bentuk nyata & $\begin{array}{l}\text { Guru BK SMA N 1 Curup Timur dan SMA N 1 Curup } \\
\text { Tengah }\end{array}$ \\
\hline 2 & $\begin{array}{l}\text { Memanggil siswa yang bermasalah dan } \\
\text { menjalankan absen siswa }\end{array}$ & Guru BK SMA N 1 Selupu Rejang \\
\hline 3 & - Melaksanakan konseling perorangan & Guru BK SMA N 1 Curup Kota \\
\cline { 2 - 2 } & - Memanggil siswa yang bermasalah & \\
\cline { 2 - 3 } & - Melaksanakan layanan klasikal & Guru BK SMA N 1 Curup Utara \\
\hline 4 & Ada yang mengajar mata pelajaran tertentu & \\
\hline
\end{tabular}


\begin{tabular}{|l|l|l}
5 & Memberikan dan menyediakan informasi tentang & Guru BK SMA N 1 Curup Selatan
\end{tabular}

karir dan pekerjaan

Tamama Rofiqah / Jurnal Kopasta 3 (2016) 32 - 39

Berdasarkan hasil wawancara pada Tabel 2 di atas, unjuk kerja guru BK pada SMA Negeri 1 Curup Timur dan SMA Negeri 1 Curup Tengah sudah baik, hal ini dapat dilihat dari bentuk nyata kinerja guru di sekolah. Pada sekolah lainnya, yaitu SMA Negeri 1 Curup Kota, unjuk kerja guru BK terlihat dari pelaksanaan layanan klasikal, layanan konseling perorangan dan pemanggilan siswa yang bermasalah, begitu pula pada SMA Negeri 1 Selupu Rejang, guru BK menjalankan absen siswa setiap hari dan juga memanggil siswa yang bermasalah. Sedangkan pada SMA Negeri 1 Curup Utara, guru BK justru mengajar mata pelajaran tertentu dan pada SMA Negeri 1 Curup Selatan guru BK memberikan serta menyediakan informasi tentang karir dan pekerjaan.

b. Upaya Pembinaan yang dilakukan oleh Kepala Sekolah dalam Meningkatkan Kompetensi Guru BK

Kepala sekolah merupakan petugas utama dalam organisasi dan administrasi pelayanan BK di sekolah.Ia memegang peranan penting dan menentukan, baik sebagai pimpinan sekolah, maupun sebagai anggota dewan bimbingan. Kepala sekolah melakukan pelatihan dan pembinaan kepada guru BK sesuai dengan tingkat pemahaman masing-masing kepala sekolah terhadap pelaksanaan BK di sekolahnya.Hal ini terjadi karena masih ditemui kepala sekolah yang belum memahami bagaimana pelaksanaan BK di sekolah. Adapun hasil wawancara tersebut dapat dilihat pada Tabel 3 berikut:

Tabel 3.Hasil Wawancara Berkenaan dengan Upaya Pembinaan yang Dilakukan oleh Kepala Sekolah

\begin{tabular}{|c|c|c|}
\hline $\begin{array}{l}\mathbf{N} \\
\mathbf{0}\end{array}$ & Upaya pembinaan & Guru yang menerima kegiatan \\
\hline 1 & 2 & 3 \\
\hline 1 & $\begin{array}{l}\text { Kepala sekolah sudah memahami pelayanan } \\
\text { BK di sekolah dengan baik }\end{array}$ & $\begin{array}{l}\text { Guru BK SMA N } 1 \text { Curup Timur dan SMA N } 1 \text { Curup } \\
\text { Tengah }\end{array}$ \\
\hline 2 & $\begin{array}{l}\text { Pemahaman kepala sekolah belum } \\
\text { menyeluruh terhadap pelayanan BK di } \\
\text { sekolah }\end{array}$ & $\begin{array}{l}\text { Guru BK SMA N } 1 \text { Selupu Rejang, SMA N } 1 \text { Curup } \\
\text { Kota, SMA N } 1 \text { Curup Utara, SMA N } 1 \text { Curup Selatan }\end{array}$ \\
\hline 3 & $\begin{array}{l}\text { Belum adanya pembinaan yang secara } \\
\text { khusus untuk guru BK }\end{array}$ & Guru BK SMAN 1 Curup Utara \\
\hline 4 & $\begin{array}{l}\text { Pembinaan ditujukan untuk seluruh guru di } \\
\text { sekolah }\end{array}$ & Guru BK SMA N 1 Curup Selatan \\
\hline 5 & $\begin{array}{l}\text { Kepala sekolah sudah memberikan berbagai } \\
\text { pembinaan kepada guru BK }\end{array}$ & $\begin{array}{l}\text { Guru BK SMA N } 1 \text { Curup Timur dan SMAN } 1 \text { Curup } \\
\text { Tengah }\end{array}$ \\
\hline
\end{tabular}

Berdasarkan hasil wawancara pada Tabel 3 di atas, bahwa upaya pembinaan yang dilakukan kepala sekolah didasari oleh pemahamannya terhadap pelaksanaan pelayanan BK di sekolah. Pada beberapa sekolah terlihat bahwa pemahaman kepala sekolah belum menyeluruh terhadap pelayanan BK. Namun, pada SMA Negeri 1 Curup Timur dan SMA Negeri 1 Curup Tengah kepala sekolah sudah memahami pelayanan BK dengan baik.

Berkenaan dengan upaya pembinaan yang dilakukan oleh kepala sekolah, secara umum pada beberapa sekolah belum ada pembinaan yang secara khusus ditujukan untuk guru BK. Hal ini senada dengan ungkapan guru BK pada SMA Negeri 1 Curup Utara yang menyatakan bahwa pembinaan dari kepala sekolah ditujukan untuk seluruh guru, sedangkan pada SMA Negeri 1 Curup Selatan, pembinaan dilakukan bersifat insidental. Namun demikian, pada SMA Negeri 1 Curup Timur dan SMA Negeri 1 Curup Tengah kepala sekolah sudah memberikan upaya pembinaan terhadap guru BK.

\section{c. Bentuk Pembinaan yang dilakukan oleh Kepala Sekolah}

Deskripsi data tentang bentuk pembinaan yang dilakukan oleh kepala sekolah dalam meningkatkan kompetensi guru BK berdasarkan hasil wawancara terhadap beberapa orang guru BK pada SMA Negeri di Kabupaten Rejang Lebong dapat dilihat pada Tabel 4 berikut: 
Tamama Rofiqah / Jurnal Kopasta 3 (2016) 32 - 39

Tabel 4.Hasil Wawancara Berkenaan dengan Bentuk Pembinaan yang dilakukan oleh Kepala Sekolah

\begin{tabular}{|c|c|c|c|c|c|c|c|}
\hline \multirow{2}{*}{$\begin{array}{l}\mathbf{N} \\
\mathbf{0}\end{array}$} & \multirow[t]{2}{*}{ Jenis Kegiatan } & \multicolumn{6}{|c|}{ Sekolah yang telah mendapatkan upaya pembinaan } \\
\hline & & $\begin{array}{l}\text { SMA } 1 \\
\text { Curup } \\
\text { Utara } \\
\end{array}$ & $\begin{array}{l}\text { SMA } 1 \\
\text { Curup } \\
\text { Timur } \\
\end{array}$ & $\begin{array}{l}\text { SMA } 1 \\
\text { Curup } \\
\text { Selatan } \\
\end{array}$ & $\begin{array}{l}\text { SMA } 1 \\
\text { Curup } \\
\text { Tengah } \\
\end{array}$ & $\begin{array}{l}\text { SMA } 1 \\
\text { Curup } \\
\text { Kota } \\
\end{array}$ & $\begin{array}{c}\text { SMA 1 } \\
\text { SelupuRejang }\end{array}$ \\
\hline 1 & Pemberian arahan saat apel pagi & $\sqrt{ }$ & - & - & - & $\sqrt{ }$ & - \\
\hline 2 & Bersifat insidental jika ada kegiatan & - & - & $\sqrt{ }$ & - & - & - \\
\hline 3 & $\begin{array}{l}\text { Kepala Sekolah ikut } \\
\text { memasyarakatkan BK }\end{array}$ & - & $\sqrt{ }$ & - & $\sqrt{ }$ & - & - \\
\hline 4 & Mengikutsertakan guru dalam seminar & - & $\sqrt{ }$ & - & $\sqrt{1}$ & - & - \\
\hline 5 & $\begin{array}{l}\text { Mendorong guru untuk mengikuti } \\
\text { pendidikan lanjutan }\end{array}$ & - & $\sqrt{ }$ & - & $\sqrt{ }$ & - & - \\
\hline 6 & $\begin{array}{l}\text { Memfasilitasi sarana prasarana } \\
\text { pelayanan BK di sekolah }\end{array}$ & $\sqrt{ }$ & $\sqrt{ }$ & $\sqrt{ }$ & $\sqrt{ }$ & $\sqrt{ }$ & $\sqrt{ }$ \\
\hline 7 & Memantau kegiatan BK & - & $\sqrt{ }$ & - & $\sqrt{1}$ & - & $\sqrt{ }$ \\
\hline 8 & Mengevaluasi kerja guru BK & $\sqrt{ }$ & $\sqrt{ }$ & $\sqrt{ }$ & $\sqrt{ }$ & $\sqrt{ }$ & $\sqrt{ }$ \\
\hline 9 & Meminta program kegiatan BK & - & $\sqrt{ }$ & - & $\sqrt{ }$ & - & $\sqrt{ }$ \\
\hline
\end{tabular}

Berdasarkan hasil wawancara pada Tabel 4 di atas, pada SMA Negeri 1 Curup Utara dan SMA Negeri 1 Curup Kota, bentuk pembinaan yang dilakukan kepala sekolah adalah memberikan arahan dan wacana terkait dengan pelaksanaan pendidikan di sekolah dilakukan saat apel pagi berlangsung. Sedangkan pada SMA Negeri 1 Curup Selatan, bentuk pembinaannya disesuaikan dengan kegiatan tertentu dan bersifat insidental. Pada SMA Negeri 1 Curup Tengah dan Curup Timur, bentuk pembinaannya berupa kepala sekolah ikut terlibat secara langsung dalam memasyarakatkan BK, mengikutsertakan guru BK dalam seminar, mendorong guru BK untuk mengikuti pendidikan lanjutan. Upaya pembinaan kepala sekolah dalam memfasilitasi sarana prasarana pelayanan BK di sekolah telah dilakukan pada 6 SMA Negeri tersebut, begitu pula dalam mengevaluasi kerja guru BK di sekolah.

Kemudian pada SMA Negeri 1 Selupu Rejang, SMA Negeri 1 Curup Tengah dan SMA Negeri 1 Curup Timur, bentuk pembinaan dari kepala sekolah berupa memantau pelaksanaan kegiatan BK, dan meminta program kegiatan BK setiap tahunnya yang dituangkan dalam bentuk program semesteran, bulanan dan mingguan.

\section{Pembahasan}

Berdasarkan hasil temuan penelitian di atas terungkap bahwa upaya pembinaan yang dilakukan oleh kepala sekolah sebagai pembina di sekolah dalam rangka meningkatkan kompetensi guru BK pada SMA Negeri di Kabupaten Rejang Lebong masih dilakukan secara umum saja.Dalam arti, pembinaan yang dilakukan bersifat umum dan ditujukan untuk seluruh guru di sekolah.Upaya pembinaan yang dilakukan oleh kepala sekolah pada dasarnya didasari oleh pemahaman kepala sekolah terhadap pelayanan BK di sekolah.Dari hasil wawancara terhadap beberapa guru BK di sekolah, dapat disimpulkan bahwa sebagian besar kepala sekolahbelum memahami secara utuh tentang pelayanan BK di sekolah.

Dalam kurikulum 2004, secara tegas dikemukakan bahwa sekolah berkewajiban memberikan pelayanan BK kepada siswa yang menyangkut tentang pribadi, sosial, belajar, dan karir. Dengan adanya kata "kewajiban", maka setiap sekolah mutlak harus menyelenggarakan pelayanan BK. Keberhasilan penyelenggaraan pelayanan BK di sekolah tidak lepas dari peran berbagai pihak di sekolah. Maju mundurnya sebuah institusi pendidikan tergantung kepala sekolah dalam mengatur sejauhmana aturan dan kedisiplinan di dalam menjalankan tugas dan fungsi masingmasing individu di dalamnya.Begitu juga dengan keberhasilan penyelenggaraan BK di sekolah khususnya, tidak lepas dari peranan berbagai pihak di sekolah.Selain guru BK atau konselor sebagai pelaksana utama penyelenggaraan bimbingan di sekolah, diperlukan juga keterlibatan kepala sekolah, guru mata pelajaran, dan wali kelas.Hasil temuan penelitian mengungkapkan bahwa masih terdapat kepala sekolah yang belum melakukan tugas sebagaimana tersebut di atas.Padahal kepala sekolah memegang peranan penting dan menentukan, baik sebagai pimpinan sekolah, maupun sebagai anggota dewan bimbingan. 
Berdasarkan hasil wawancara, berkenaan dengan tugas kepala sekolah dalam melakukan pembinaan terhadap guru BK, terungkap bahwa pembinaan yang dilakukan ada yang bersifat insidental, dilakukan saat apel pagi berlangsung, memantau kegiatan BK, mengevaluasi kerja guru BK dan meminta program kerja BK. Padahal,

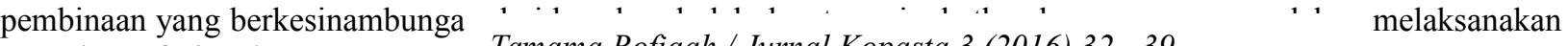
tugas keprofesionalannya.

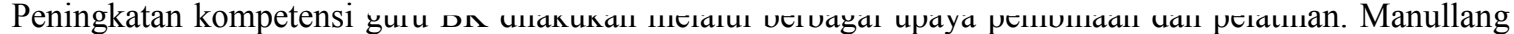
(dalam Sunoko, 2010) menjelaskan bahwa agar seseorang mampu bekerja dengan baik diperlukan latihan khusus. Lebih lanjut Tani (dalam Sunoko, 2010) mengemukakan bahwa pelatihan dimaksudkan untuk memperbaiki penguasaan berbagai keterampilan dan teknik pelaksanaan pekerjaan tertentu serta juga persiapan untuk melakukan pekerjaan. Dengan demikian, pembinaan yang dilakukan dapat memperbaiki dan meningkatkan kinerja guru BK di sekolah.

\section{Penutup}

Guru merupakan komponen situasi dan interaksi pendidikan yang berada pada posisi aktif mengembangkan proses pembelajaran yang memfasilitasi peserta didik dalam mencapai tujuan pendidikan. Pembelajaran mengandung arti setiap kegiatan yang dirancang untuk membantu seseorang mempelajari suatu kemampuan dan atau nilai yang baru. Demikian berat dan pentingnya tugas seorang guru, maka guru harus dibekali dengan kemampuan profesional, sehingga mampu melaksanakan proses pembelajaran sesuai dan berdasarkan standar pengetahuan dan kompetensi guru dengan tanggung jawab yang tinggi sebagai bagian dari kepribadiannya seperti terlihat pada kehidupannya, baik tujuan yang bersifat duniawi maupun ukhrowi.

Dan untuk mewujudkan guru yang memiliki kemampuan profesional dalam menjalankan tugas dan kewajibannya, diperlukan pembinaan dari kepala sekolah sebagai seorang pembina. Pembinaan merupakan kegiatan atau usaha untuk merangsang, mengkoordinasi dan membimbing pertumbuhan guru-guru sehingga lebih dapat memahami dan lebih efektif penampilannya dalam proses pembelajaran. Pembinaan dapat dilakukan dalam berbagai bentuk dan teknik baik yang bersifat individual maupun kelompok

Upaya pembinaan yang dilakukan kepala sekolah berkenaan dengan kompetensi guru BK di sekolah belum dilaksanakan secara khusus, melainkan pembinan secara umum yang ditujukan untuk seluruh guru di sekolah.Sebagian besar bentuk pembinaan yang dilakukan oleh kepala sekolah berupa pengarahan, bimbingan dan dorongan kepada guru BK.

\section{Daftar Pustaka}

A.Muri Yusuf. (2005). Metodologi Penelitian.Dasar-dasar Penyelidikan Ilmiah. Padang: UNP Press.

Damsar.(2011). Pengantar Sosiologi Pendidikan. Prenada Media Group: Jakarta.

Kurniawan.(2010). "Kompetensi Profesional Konselor Sekolah Menengah Negeri Se-Kota Banda Aceh dan Implikasinya bagi Pemerintah Kota Banda Aceh".Tesis tidak diterbitkan.Padang: Program Pascasarjana UNP.

Mega Iswari.(2010). Kompetensi Guru Sekolah Luar Biasa dalam Melaksanakan Layanan Bimbingan dan Konseling.Jurnal Forum Pendidikan, Vol. 36. Padang: UNP Press.

Mulyasa (2003).Kurikulum Berbasis Kompetensi : Konsep, Karasteristik dan Implementasi. Remaja Rosdakarya : Bandung.

(2007). Standar Kompetensi dan Sertifikasi Guru.. Remaja Rosda Karya: Bandung.

Oemar Hamalik (2002). Pendidikan Guru berdasarkan Pendekatan Kompetensi. Bumi Aksara: Jakarta.

Peraturan Pemerintah Republik Indonesia No. 19 Tahun 2005 tentang Standar Nasional Pendidikan.

Peraturan Pemerintah No. 27 Tahun 2008 tentang SKAKK.

Prayitno.dkk. (1997).Seri Pemandu Pelaksanaan Bimbingan dan Konseling di Sekolah (SPP-BKS) Buku III. Penerbit Ikrar Mandiri: Jakarta.

(2005). Studi Pengembangan Aplikasi High-Touch dan High- Tech dalam Proses Pembelajaran di Sekolah. Penelitian Hibah Pascasarjana Tahun Pertama.

.(2010). Penilaian Kinerja Konselor, Kompetensi dan Indikatornya. Program Pendidikan Profesi Konselor. Jurusan Bimbingan dan Konseling.Padang: FIP UNP.

Sahertian.(2000). Konsep Dasar dan Teknik Supervisi Pendidikan dalam Rangka Mengembangkan Sumber Daya Manusia.Penerbit Adi Mahasatya: Jakarta. 
Sunoko.(2011). Pembinaan Profesional Guru (Studi Pembinaan oleh Kepala Sekolah, Pengawas dan Dinas Pendidikan di SMP Negeri 2 Sarolangun). Disertasi.Tidak diterbitkan. Program Pascasarjana UNP.

Syaiful Bahri Djamarah. (2001). Guru dan Anak Didik dalam Interaksi Edukatif. Rineka Cipta: Jakarta.

Syaefudin.(2009). Pengembangan Profesi Guru. Alfabeta: Bandung.

Undang-undang No.14 Tahun 2005 tentang Guru dan Dosen. 